\title{
Effectiveness of Inorganic Fertilizer and Biofertilizer Application on Maize Yield and Fertilizer Use Efficiency on Inceptisol from West Java
}

\author{
Jati Purwani* and Nurjaya \\ Indonesian Soil Research Institute (ISRI), Jalan Tentara Pelajar No 12, Bogor 16114. Indonesia. \\ *email: jati_purwani6243@yahoo.com
}

Received Agustus 20, 2019; Revised December 8, 2019; Accepted 10 December 2019

\begin{abstract}
The study about the effectiveness of inorganic fertilizer and bio-fertilizer application on maize yield and fertilizer use efficiency has been carried out in the greenhouse using Inceptisol from Dukuh Village, Cibungbulang District, Bogor Regency. Inorganic fertilizers used were Urea, SP36 and KCl, the biofertilizer used consisted of Azospirillum sp., Azotobacter sp., Bacillus sp., and Lactobacillus sp.. The study was arranged in a Randomized Block Design consisting of seven treatments and six replications. The treatments consisted of various dosages of inorganic fertilizers combined with bio-fertilizer, namely 1) Control (without fertilizer), 2) 100\% recommended NPK level, 3) Biofertilizer, 4) 25\% recommended NPK level+Biofertilizer, 5) 50\% recommended NPK level+Biofertilizer, 6) 75\% recommended NPK level + Biofertilizer, 7) $100 \%$ recommended NPK level + Biofertilizer. The results showed that the application of inorganic NPK ferttilizers and biofertilizer on maize cultivation on Inceptisol from Dukuh Village, Cibungbulang District, Bogor Regency resulted in an increase of maize yield compared to the recommended level of inorganic fertilizers ( $100 \%$ NPK). The treatment of NPK ( $50 \%$ recommended level)+Biofertilizer resulted in the highest biomass dry weight, yield of corn and value of RAE (Relative Agronomic Effectiveness). The shoot dry weight was $138.09 \mathrm{~g} \mathrm{pot}^{-1}$, corn yield was $190.87 \mathrm{~g} \mathrm{pot}^{-1}$, and RAE value was $113.44 \%$. The optimum doses of NPK fertilizers were $200 \mathrm{~kg}$ Urea ha- ${ }^{-1}, 60 \mathrm{~kg} \mathrm{SP}^{-3} 6 \mathrm{ha}^{-1}$ and $45 \mathrm{~kg} \mathrm{KCl} \mathrm{ha}^{-1}$ combined with $4 \mathrm{~L} \mathrm{ha}^{-1}$ biofertilizer.
\end{abstract}

Keywords: Biofertilizer, corn yield, fertilizer use efficiency, inorganic fertilizer, Inceptisols

\begin{abstract}
ABSTRAK
Penelitian untuk menentukan efektivitas aplikasi pupuk anorganik dan hayati pada hasil jagung dan efisiensi penggunaan pupuk telah dilakukan di rumah kaca menggunakan tanah Inceptisol dari Desa Dukuh, Kecamatan Cibungbulang, Kabupaten Bogor. Pupuk anorganik yang digunakan adalah Urea, SP36 dan KCl, dan pupuk hayati yang digunakan terdiri dari konsorsium bakteri Azospirillum sp., Azotobacter sp., Bacillus sp., dan Lactobacillus sp.. Penelitian ini disusun dalam rancangan acak kelompok yang terdiri dari tujuh perlakuan dengan enam ulangan. Perlakuan terdiri dari berbagai tingkat dosis pupuk anorganik yang dikombinasikan dengan pupuk hayati, yaitu 1) Kontrol (tanpa pupuk), 2) NPK (tingkat rekomendasi 100\%), 3) Pupuk hayati, 4) NPK (tingkat rekomendasi 25\%) + pupuk hayati, 5) NPK (tingkat rekomendasi 50\%) + pupuk hayati, 6) NPK (tingkat rekomendasi $75 \%$ ) + pupuk hayati, 7) NPK (tingkat rekomendasi 100\%) + pupuk hayati. Hasil penelitian menunjukkan bahwa aplikasi pupuk anorganik dan hayati pada pertanaman jagung pada Inceptisol dari Desa Dukuh, Kecamatan Cibungbulang, Kabupaten Bogor memberikan peningkatan hasil jagung dibandingkan dengan tingkat rekomendasi pupuk anorganik (NPK 100\%). Perlakuan NPK (tingkat rekomendasi 50\%) + pupuk hayati menghasilkan bobot kering batang, hasil jagung dan nilai RAE (RelativeAgronomicEffectiveness) paling tinggi. Berat kering batang adalah 138,09 $\mathrm{g} \mathrm{pot}^{-1}$, hasil jagung adalah $190,87 \mathrm{~g} \mathrm{pot}^{-1}$, dan nilai RAE adalah $113,44 \%$. Dosis

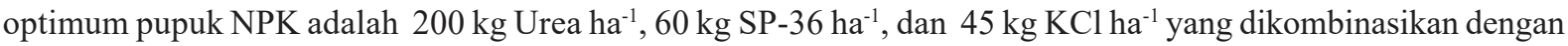
$4 \mathrm{~L} \mathrm{ha}^{-1}$ pupuk hayati.
\end{abstract}

Kata Kunci: Efisiensi penggunaan pupuk, hasil jagung, Inceptisols, pupuk anorganik, pupuk hayati 


\section{INTRODUCTION}

Maize (Zea mays) is the second food commodity after rice for most of Indonesian people. Maize plants have high adaptability, so that they can grow well on fertile to marginal soils. To meet the needs on corn, it can be fulfilled through the development of maize plantation areas in upland agroecosystems that are generally dominated by Ultisols and Inceptisols. However, the main problems of maize plant growth on Ultisols and Inceptisols are low soil $\mathrm{pH}$ and $\mathrm{CEC}$, high saturation of $\mathrm{Al}$, high $\mathrm{Al}, \mathrm{Fe}$ and Mn contents, low nutrient contents (N, P and K), very sensitive to erosion (Nursyamsi 2004; Kasno et al. 2006), and low organic matter content (Simanungkalit 2001; Matsumoto et al. 2003).

The low productivity of the acid soils is caused by various factors, such as drought, plant spacing or plant density, and unbalanced or excessive fertilization. Maize plants require large amount of fertilizer for different growth periods. The long term application of chemical fertilizers and pesticides have caused negative impacts on soil, water and agricultural environment. Utilization of biological fertilizers can improve soil fertility, plant productivity, biological activities in the rhizosphere, and reduce excessive inorganic fertilizer use (Wu et al. 2005). Biofertilizer contains several microbes that can improve plant nutritional status (Malusá \& Vassilev 2014) and play an important role in the vegetative growth of plants (Wong et al. 2015), while Bhardwaj et al. (2014) indicate that biological fertilizers play an important role in plant tolerance to abiotic and biotic stress, reducing $\mathrm{Al}$ and $\mathrm{Fe}$ toxicity, and stimulating plant growth (Rahman et al. 2018).). Organic substances in soil are mined by microbes through enzymatic processes and turned them into nutrients (N, P, and $\mathrm{K}$ ) that are useful for plants (Rahmansyah et al. 2009; Bais et al. 2006)

Bacteria including Azotobacter, Azospirillum, Pseudomonas, and Rhizobium play an important role in increasing plant growth (Zahir et al. 2004), while the bacteria of Pseudomonas, Micrococcus, Bacillus, Azotobacter, Mycrobacterium, Enterobacter, Klebsiella, and Flavobacterium have ability to dissolve P (Purwaningsih 2003). The mineralization processes of macro and micro nutrients in soil can be accelerated by the presence of $\mathrm{N}$-fixing and $\mathrm{P}$ solubilizing bacteria and root exudates to support plant growth. The use of microbes is intended to reduce the chemical fertilizer use through enzymatic processes.

Biofertilizers are renewable, inexpensive and environmentally friendly. They are increasingly popular in the past decade in Asia, especially for agricultural and food production (McCarty et al.
2017). The frequent use of biofertilizers indicates that the biofertilizers have the prospect to become an alternative fertilizer for rational and environmentally friendly fertilizer management in order to improve fertilizer use efficiency. Various studies indicate that the application of biofertilizers in accordance with the functional characters of inoculants has been able to reduce the use of N, P, $\mathrm{K}$ fertilizers. Free-living (non-symbiotic) N-fixing bacteria, such as Azotobacter sp. and Azospirillum $\mathrm{sp}$. are able to contribute to plant $\mathrm{N}$ needs between 10-46 kg ha-1 year-1, while Rhizobium sp. in symbiotic relationship with legume plants can contribute higher amount of $\mathrm{N}$, reaching $63.2 \mathrm{~kg} \mathrm{~N}$ ha $^{-1}$ season $^{-1}$ or $45.4 \%$ of the total plant requirement (Simanungkalit et al. 2006). The specific microbes are often used in biofertilizers, such as N-fixing bacteria and $\mathrm{P}$ - and $\mathrm{K}$-solubilizing microbes. The $\mathrm{N}$-fixing microbe groups include Rhizobium sp., Azospirillum sp. and Azotobacter sp. Aspergilus sp., Pseudomonas sp., and Lactobacillus sp. are capable to dissolve P(Isroi 2008). The use of biofertilizers reduces energy consumption and increases the availability of nutrients for plants (Stamford et al. 2014). Biological nitrogen fixation consumes about $25 \%$ to $30 \%$ less energy than the chemical fertilizers (Asmitha et al. 2019)

The objective of this study was to examine the use of a biofertilizer formula containing of Azospirillum sp., Azotobacter sp., Bacillus sp., and Lactobacillus sp. to increase maize growth and yield and chemical fertilizer use efficiency.

\section{MATERIALS AND METHODS}

\section{Study Site}

A biofertilizer containing of Azospirillum sp., Azotobacter sp., Bacillus sp., and Lactobacillus $\mathrm{sp}$. was formulated in a liquid medium. The study of the effect of biofertilizer application on maize growth and yield was carried out in the greenhouse of the Soil Research Institute in Cimanggu, Bogor using Inceptisol soil sample from Cibungbulang, Bogor. The soil sample was taken at $0-20 \mathrm{~cm}$ depth and then air-dried. Dried soil was passed into a $2 \mathrm{~mm}$ sieve. After that, the soil was put into pots as much as $20 \mathrm{~kg}$ each.

\section{Experimental Design}

A factorial treatment in a completely randomized design with six replicates was used in the study. The treatments were arranged in various dosage levels of inorganic fertilizers combined with biofertilizer. They were P1 (control/without 
fertilizer), P2 (100\% NPK recommended level), P3 (biofertilizer), P4 (25\% NPK recommended level + biofertilizer), P5 (50\% NPK recommended level + biofertilizer), P6) (75\% NPK recommended level + biofertilizer), P7 (100\% NPK recommended level + biofertilizer). The standard NPK recommendation level was $350 \mathrm{~kg}$ Urea ha ${ }^{-1}, 100 \mathrm{~kg} \mathrm{SP}-36 \mathrm{ha}^{-1}, 75$ $\mathrm{kg} \mathrm{KCl} \mathrm{ha-1}$, while the dosage of biofertilizer used was $4 \mathrm{~L} \mathrm{ha}^{-1}$.

\section{Application of the Treatments}

The soil in the pots was mixed with dolomite and cow manure compost that are equivalent to 1 $\mathrm{Mg} \mathrm{ha}^{-1}\left(18.75 \mathrm{~g} \mathrm{pot}^{-1}\right)$ and $2 \mathrm{Mg} \mathrm{ha}^{-1}\left(37.5 \mathrm{~g} \mathrm{pot}^{-1}\right)$, respectively, in which both dolomite and cow manure were used as basic fertilizers. After that, the mixture was incubated for one week. Urea, SP-36 and $\mathrm{KCl}$ were applied based on the results of soil test using "Upland Soil Test Kit" from ISRI (Indonesian Soil Research Institute). The recommended levels derived from the tool were Urea $\left(350 \mathrm{~kg} \mathrm{ha}^{-1}\right)$, SP-36 (100 kg ha-1), and $\mathrm{KCl}\left(75 \mathrm{~kg} \mathrm{ha}^{-1}\right)$. Urea was applied twice, at 1 to 2 weeks after planting (WAP) and at 4 to 5 WAP. The dosages of Urea, SP-36, and $\mathrm{KCl}$ applied were adjusted according to the treatments.

Biofertilizer was applied for four times during maize growth periods, i.e. 7 days before planting (DBP), 7 days after planting (DAP), 14 DAP, and 21 DAP with the dosage of $1 \mathrm{~L} \mathrm{ha}^{-1}$ for each period.
Biofertilizer was diluted as much as $3 \mathrm{~mL} \mathrm{~L}^{-1}$ and sprayed evenly on the soil surface. The remaining biofertilizer solution was poured to the soil. Biofertilizer was applied at $6.00-8.00$ am or between 16.00-17.00 pm. About five maize seeds were planted in each pot after seven days of the incubation of cow manure and dolomite. On the $5^{\text {th }}$ day after planting, the maize plant was kept for only two plants in all pots. Measurement on the plant height and number of leaves was carried out every week until the flowering period, while the determination of biomass and maize yield was carried out at harvest time. Relative Agronomic Effectiveness (RAE) was calculated by Machay et al. (1984) formula:

$$
\mathrm{RAE}=\frac{(\text { Yield of tested by biofertilizers }- \text { Control })}{(\text { Yield of recommended fertilizer }(\text { standard })-\text { Control })} \times 100 \%
$$

\section{Statistical Analysis}

The data obtained were analyzed using Analysis of Variance (ANOVA) and the differences of the mean among the treatments were analyzed by Duncan's Multiple Range Test (DMRT) at the level of $p=0.05$.

\section{RESULTS AND DISCUSSION}

\section{Soil Characteristics}

Chemical and physical characteristics of Inceptisol are presented in Table 1. The results

Table 1. Characteristics of Inceptisol from Cibungbulang, Bogor, West Java.

\begin{tabular}{lcc}
\hline \multicolumn{1}{c}{ Soil characteristic } & Value*) & Criteria**) \\
\hline Texture : & & \\
Sand (\%) & 10 & Clay \\
Silt (\%) & 39 & \\
Clay (\%) & 51 & \\
$\mathrm{pH}:$ & & \\
$\mathrm{H}_{2} \mathrm{O}$ & 5.70 & Slightly Acid \\
$\mathrm{KCl}$ & 4.80 & - \\
Organic-C $(\%)$ & 1.14 & Low \\
Total N $(\%)$ & 0.13 & Very Low \\
$\mathrm{C} / \mathrm{N}$ Ratio & 9 & Moderate \\
Potential-P $(\mathrm{HCl} 25 \%)$ & 102 & Very High \\
Available-P $\left(\mathrm{Olsen}^{*}\right)(\mathrm{ppm})$ & 2.0 & Very Low \\
$\mathrm{CEC}:$ & & \\
$\mathrm{Ca}\left(\mathrm{cmol}(+) \mathrm{kg}^{-1}\right)$ & 8.13 & Moderate \\
$\mathrm{Mg}\left(\mathrm{cmol}(+) \mathrm{kg}^{-1}\right)$ & 6.40 & High \\
$\mathrm{K}\left(\mathrm{cmol}(+) \mathrm{kg}^{-1}\right)$ & 1.24 & Low \\
$\mathrm{Na}\left(\mathrm{cmol}(+) \mathrm{kg}^{-1}\right)$ & 0.21 & Low \\
Total $\left(\mathrm{cmol}(+) \mathrm{kg}^{-1}\right)$ & 15.78 & Low \\
Base saturation $(\%)$ & $>100$ & Very High \\
$\mathrm{Al}{ }^{3+}$ & 0.00 & Very Low \\
\hline
\end{tabular}


showed that Inceptisol from Cibungbulang, Bogor has slightly acid soil reaction ( $\mathrm{pH} 5.70)$, low organicC content $(1.14 \%)$, very low total-N $(0.13 \%)$, and moderate $\mathrm{C} / \mathrm{N}$ ratio. The potential-P (extracted with $25 \% \mathrm{HCl}$ ) is classified as very high but the available$\mathrm{P}$ was very low. To improve the use efficiency of $\mathrm{P}$ fixed in the soil, it is required biofertilizer containing P-solubilizing bacteria.

The amount of exchangeable-Ca is classified as moderate, exchangeable- $\mathrm{Mg}$ is relatively high, while the exchangeable-K and -Na are low. Cation exchange capacity (CEC) is classified as low, but the level of base saturation is very high. The high base saturation is caused by the free cations in the soil solution other than those contained in the exchange complex. The results show that the main problems of Inceptisol from Cibungbulang, Bogor are acid soil reaction, low organic- $\mathrm{C}$ content, very low total $\mathrm{N}$ and available $\mathrm{K}$, and low CEC. Although the soil P (P-potential) content is relatively high, however, its availability level is relatively low. Therefore, the Inceptisol from Cibungbulang, Bogor has a relatively low fertility level. The main problem is that there is an imbalance nutrient content of $\mathrm{Ca}$ and $\mathrm{Mg}$ in moderate and high levels, very low $\mathrm{N}$ and $\mathrm{P}$, and low K content. Lower doses of NPK fertilizers combined with biological fertilizer containing inoculants of $\mathrm{N}$-fixing microbes and phosphate solubilizing bacteria are well known potential for fertilizer use efficiency compared to the recommended NPK level.

\section{Effect of NPK and Biofertilizer on Plant Height}

Plant height measurements at 1 to 7 WAP are presented in Figure 1. The results show that in the first to fourth week, no significant differences in the plant heights among all the treatments were observed in comparison to that in P1 (control treatment/without fertilizer). In the $5^{\text {th }} \mathrm{WAP}$, the P3 treatment (biofertilizer) resulted in higher plant height than P1 (control treatment) and P2 (recommended dosage). Plant height in P1 treatment (without fertilizer), P2 (recommended NPK level) and P3 (biofertilizer) were 102.06, 93.59, and $102.78 \mathrm{~cm}$, respectively. These data showed that nutrient requirements for plant growth up to 5 WAP were thought to have been fulfilled by the nutrients contained in the soil and the addition of manure as much as $2 \mathrm{Mg} \mathrm{ha}^{-1}$. According to Santosa (2009) the addition of organic-C on Inceptisols can increase the activity of Psolubilizing bacteria (PSB) and other soil microbes, namely the increases in dehydrogenase enzyme activity, $\mathrm{CO}_{2}$-soil production, and available $\mathrm{P}$ levels. Therefore, the organic-C content of the soil must be increased. Application of organic fertilizer will increase the organic-C that can be utilized by soil microbes, so that it can increase the activity of microbes inoculated into the soil.

Plant height at 7 WAP in the combination treatments of chemical fertilizers and biofertilizer showed higher measures than those in P1 (control) and P2 (recommended NPK level) treatments (Table

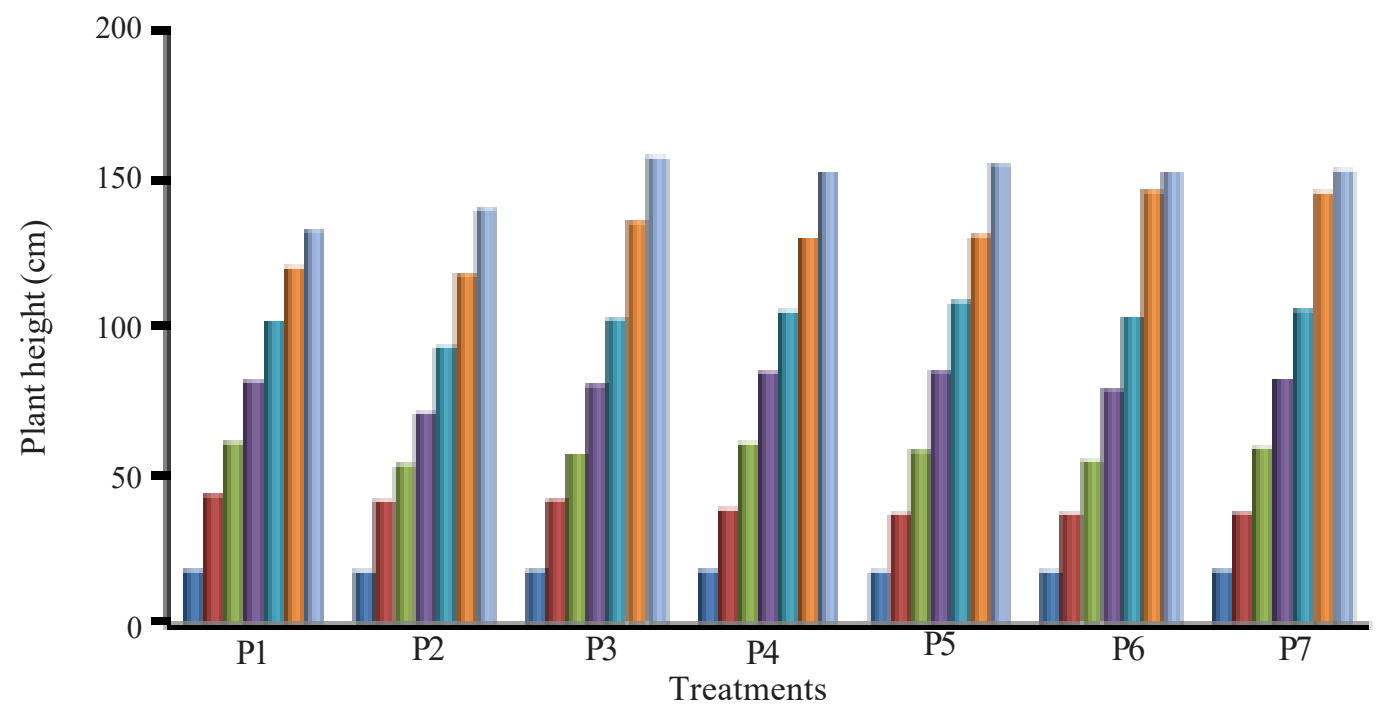

Figure 1. Plant height at 1 until 7 WAP in response to the NPK level combined with biofertilizer. Note: P1 (Control), P2 (100\% recommended NPK level), P3 ( Biofertilizer), P4 (25\% recommended NPK level+Biofertilizer), P5 (50\% recommended NPK level+Biofertilizer), P6 (75\% recommended NPK level+Bio-fertilizer, P7 (100\%

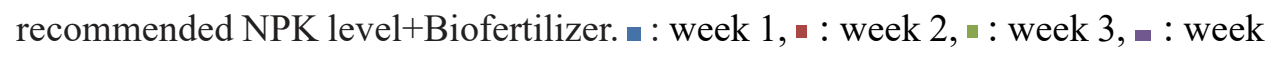
$4, \approx$ : week $5, \because$ : week $6, \approx$ : week 7 . 
Table 2. Plant height and number of leaf at 7 WAPin response to the NPK level combined with biofertilizer.

\begin{tabular}{rlcc}
\hline Code & Treatment & Plant height $(\mathrm{cm})$ & Number of leaf \\
\hline P1 & Control & $133.08 \mathrm{a}$ & $10.42 \mathrm{a}$ \\
P2 & NPK (100\% recommended level) & $139.96 \mathrm{a}$ & $12.25 \mathrm{~b}$ \\
P3 & Biofertilizer & $157.28 \mathrm{bc}$ & $10.08 \mathrm{a}$ \\
P4 & NPK (25\% recommended level) + Biofertilizer & $178.96 \mathrm{c}$ & $13.25 \mathrm{ba}$ \\
P5 & NPK (50\% recommended level) + Biofertilizer & $155.13 \mathrm{~b}$ & $13.83 \mathrm{~d}$ \\
P6 & NPK (75\% recommended level)+Biofertilizer & $152.46 \mathrm{ab}$ & $13.42 \mathrm{c}$ \\
P7 & NPK (100\% recommended level)+Biofertilizer & $153.08 \mathrm{ab}$ & $13.33 \mathrm{c}$ \\
\hline & CV $(\%)$ & 4.84 & 6.77 \\
\hline
\end{tabular}

Note: The numbers followed by the same letters in the same column show no significant difference at 5\% DMRT.

2). This also occured for the leaf number, thus it was assumed that bacteria/microorganisms contained in the biofertilizer can produce hormones that can stimulate plant growth. Wong et al. (2015) stated that there are types of biofertilizers containing microbe producing growth regulator compounds. Application of $\mathrm{N}$-fixing bacteria and $\mathrm{P}$-solubilizing bacteria on maize cultivation increased plant height, root and shoot weight, number of grains per cob, and maize yield (Beyranvand et al. 2013). Addition of $\mathrm{N}$ and $\mathrm{P}$ fertilizers is needed to achieve maximum yield (Farnia and Ashjardi 2015). Besides increasing maize yield, application of P-solubilizing bacteria in combination with $\mathrm{P}$ chemical fertilizer can be a strategy to achieve sustainable agriculture (Yosefi et al. 2011). P-solubilizing bacteria can improve plant productivity by dissolving insoluble-P and stimulate plant growth by producing hormones, vitamins, and other growth factors (Bhattacharya and Jain 2000).

\section{Effect of NPK and Biofertilizer on Number of Leaf}

The number of leaf in response to the level of chemical fertilizers combined with biofertilizer is presented in Figure 2. The results showed that the combination of chemical fertilizers and biofertilizer on $\mathrm{P} 4, \mathrm{P} 5, \mathrm{P} 6, \mathrm{P} 7$ treatments produced higher number of leaf than those on P1 (control treatment). The effects of combination treatments of NPK level with biofertilizer on the leaf number are shown in Figure 2. At 7 WAP, P4, P5, P6, and P7 treatments showed relatively higher number of leaf compared

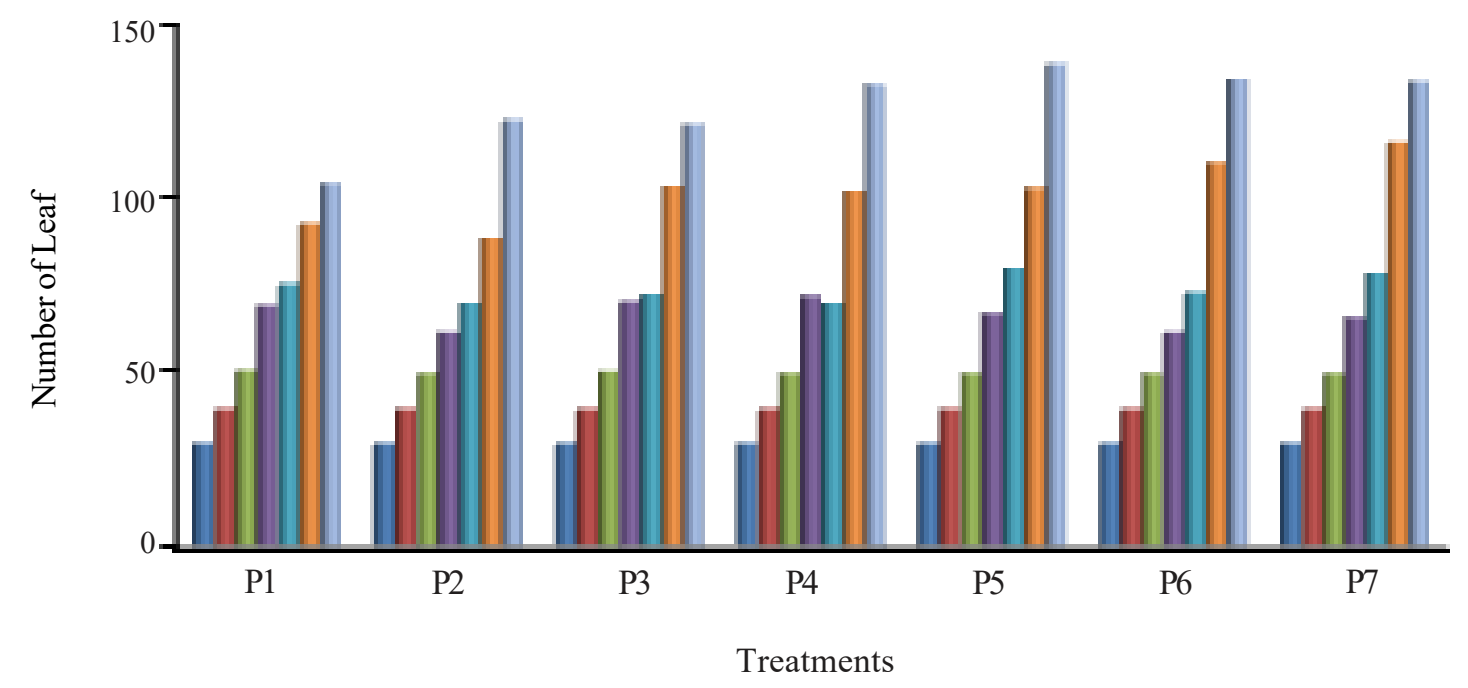

Figure 2. Number of leaf at 1 until 7 WAP in response to the NPK level combined with biofertilizer. Note: P1 (Control), P2 (100\% recommended NPK level), P3 (biofertilizer), P4 (25\% recommended NPK level + biofertilizer), P5 (50\% recommended NPK level + biofertilizer), P6 (75\% recommended NPK level + biofertilizer), P7 (100\% recom-

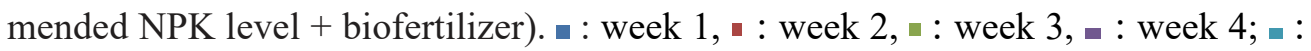
week 5, : : week $6,-$ : week 7 . 
to P2 (recommended NPK level) (Table 2). Quantitatively, the highest number of leaf (13.83 plant $\left.^{-1}\right)$ was achieved in the P5 treatment $(50 \%$ NPK recommended level + biofertilizer), meanwhile the P2 (100\% NPK recommended level) and P3 (biofertilizer) treatments resulted in lower leaf number, i.e. 12.25 and 12.13 plant $^{-1}$, respectively. In addition, P1 (control) treatment resulted in 10.42 plant $^{-1}$.

\section{Effect of NPK and Biofertilizer on Plant Biomass}

Table 3 shows that the treatment of P3 (biofertilizer) did not result in significant effects in increasing fresh and dry weight of maize shoots compared to P1 (control). The treatment of N, P, K combined with biological fertilizer showed significant increases in shoot and root weight compared toP3 (biofertilizer treatment). The treatment of N, P, K fertilizer combined with biofertilizer significantly increased the fresh and dry weight of shoots as well as roots compared to $\mathrm{P} 2$ (100\% recommended NPK level) and P3 (biofertilizer) treatments. These results can be explained that complete application of fertilizers (chemical and bio-fertilizers) provides better plant growth. Several supporting studies include the balanced and optimal use of N, P, and K fertilizers that play an important role in improving maize yield (Ashgar et al. 2010), contributing of 40$45 \%$. Nitrogen fertilization increases maize plant biomass up to $25-42 \%$ (Ogola et al. 2002), while plants can only utilize $5-20 \%$ of the applied Pfertilizer (Isgitani 2005).
The treatment of P2 (NPK 100\% recommended level) increased fresh and dry weight of maize shoots compared to P1 (control) and P3 (biofertilizer). The treatments of chemical and biofertilizer combinations of P5 (NPK 50\% recommended level+biofertilizer), P6 (NPK 75\% recommended level+biofertilizer) and P7 (NPK $100 \%$ recommended level + biofertilizer) showed significant increases of fresh and dry weight of shoots compared to P2 (NPK 100\% recommended level, without combination with biofertilizer).

The application of biofertilizer (P3) showed lower root dry weight compared to P1 (control treatment), although both were not significantly different, while fresh and dry weight of shoots increased with the addition of biofertilizer (P3 treatment) compared to P1 (control). This result indicates that the increase in root weight does not necessarily lead to better plant growth. It was assumed that nutrient translocation from roots to shoots in biofertilizer (P3) treatment was relatively small so it did not affect the growth of shoots. On the other hand, the root dry weight in P2 (recommended NPK level treatment) increased significantly compared to that in P1 (control) and P3 (biofertilizer) treatments.

The highest fresh and dry weight of shoots and dry weight of roots were achieved in P4 $(25 \%$ recommended NPK level + biofertilizer) treatment. This result showed that the nutrients needed for vegetative growth of maize plants were provided sufficiently by applying $25 \%$ recommended NPK level + biofertilizer. Thus, the use of NPK fertilizers

Table 3. Fresh and dry weight of shoots and roots, and root length in response to the NPK level combined with biofertilizer

\begin{tabular}{|c|c|c|c|c|c|}
\hline \multirow{2}{*}{ Code } & \multirow{2}{*}{ Treatment } & FWS & DWS & DWR & \multirow{2}{*}{$\begin{array}{ll}\mathrm{RL} \\
\ldots . \mathrm{cm} \ldots .\end{array}$} \\
\hline & & \multicolumn{3}{|c|}{ 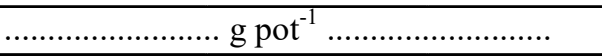 } & \\
\hline P1 & Control & $164.69 \mathrm{a}$ & $92.71 \mathrm{a}$ & $11.89 \mathrm{a}$ & $42.50 \mathrm{a}$ \\
\hline P2 & NPK $(100 \%$ recommended level $)$ & $225.33 \mathrm{~b}$ & $104.55 \mathrm{ab}$ & $16.49 \mathrm{~b}$ & $42.50 \mathrm{a}$ \\
\hline P3 & Biofertilizer & $182.06 \mathrm{a}$ & $97.79 \mathrm{a}$ & $9.30 \mathrm{a}$ & $42.25 \mathrm{a}$ \\
\hline P4 & $\begin{array}{l}\text { NPK }(25 \% \text { recommended level })+ \\
\text { Biofertilizer }\end{array}$ & $246.84 \mathrm{~b}$ & $115.17 \mathrm{~b}$ & $20.58 \mathrm{c}$ & $51.00 \mathrm{a}$ \\
\hline P5 & $\begin{array}{l}\text { NPK }(50 \% \text { recommended level })+ \\
\text { Biofertilizer }\end{array}$ & $285.42 \mathrm{c}$ & $138.09 \mathrm{c}$ & $14.87 \mathrm{~b}$ & $49.50 \mathrm{a}$ \\
\hline P6 & $\begin{array}{l}\text { NPK }(75 \% \text { recommended level })+ \\
\text { Biofertilizer }\end{array}$ & $276.13 b c$ & $128.02 \mathrm{~b}$ & $11.70 \mathrm{ab}$ & $46.50 \mathrm{a}$ \\
\hline P7 & $\begin{array}{l}\text { NPK }(100 \% \text { recommended level })+ \\
\text { Biofertilizer }\end{array}$ & $313.83 \mathrm{c}$ & $136.13 \mathrm{c}$ & $13.10 \mathrm{ab}$ & $51.25 \mathrm{a}$ \\
\hline & CV (\%) & 12.54 & 9.70 & 30.71 & 9.89 \\
\hline
\end{tabular}

Note : The numbers followed by the same letters in the same column show no significant difference at $5 \%$ DMRT. FWS = fresh weight of shoots, DWS = dry weight of shoots, DWR = dry weight of roots, RL= root length. 
can be reduced up to $75 \%$ of the recommended level to fulfill the nutrients needed for maize growth until 7 WAP. Measurement on root length indicated that all the treatments did not show any significant effects. Zahir et al. (2004) reported that the use of phosphate solubilizing microorganisms significantly improved maize plant growth, both qualitatively and quantitatively. The study by Naserirad et al. (2011) and Rokhzadi et al. (2008) showed that inoculation of biofertilizers containing Azotobacter and Azospirillum increased plant height, number of leaf per plant, and corn weight compared to those without biofertilizer.

\section{Effect of NPK and Biofertilizer on Maize Yield}

Application of biofertilizer (P3) on Inceptisol affected the weight of corn+cobs, grains, and 100 grains, however, they were not significantly different from those in P1 (control treatment). The application of N, P and $\mathrm{K}$ fertilizers increased maize yield. The weight of corn in the P2 treatment $(100 \%$ recommended NPK level) was not significantly different from that in P7 (100\% recommended NPK level + biofertilizer) treatment. In seems that the use of biofertilizer combined with standard NPK level did not increase the maize yield. The highest maize yield was obtained in $\mathrm{P} 5$ (50\% recommended NPK level + biofertilizer) treatment amounting about $223.84 \mathrm{~g} \mathrm{pot}^{-1}$, which showed significant differences compared to that in $\mathrm{P} 2$ treatment (100\% recommended NPK level) and other treatments. The yield of maize in P5 (50\% recommended NPK level+biofertilizer) was $13.20 \%$ higher compared to that in P2 (100\% recommended NPK level) (Table 4). Therefore, the application of biofertilizer can increase the maize yield, besides that it makes use of NPK fertilizers more efficient as much as $50 \%$ of the recommended level. The same results were indicated by Mahato and Neupane (2017), which showed that the combination of chemical fertilizers and biofertilizer provides higher yields of corn than the use of chemical fertilizers, thus reducing the amount of chemical fertilizers used during cultivation. According to Zarabi et al. (2011), adding organic fertilizer will increase water use efficiency, optimize photosynthesis and stimulate plant growth and development.

The effects of biofertilizer (P3) treatment on the dry weight of corn, grains, and 100 grains did not show significant different from those in the control (P1) treatment. This result shows that to achieve high maize yield, the application of biological fertilizer alone is not enough, so that it must be combined with chemical fertilization of Urea, SP36 and $\mathrm{KCl}$. To achieve high maize yield on the Inceptisols, it is sufficient to use 50\% NPK recommended level along with biofertilizer (Table 4). This phenomenon may be due to biofertilizer application affects minerals in the soil to release $\mathrm{P}$ and increase its availability in the soil for plant uptake. The results are consistent with the findings of Mahdi et al. (2010); Sivamurugan et al. (2018). Azotobacter also affects significantly the dry weight of corn and maize plant biomass through increasing plant height and root weight (Mahato and Neupane 2017). The application of commercial biofertilizer Nitragin containing of Azotobacter, Azospirillum, and Pseudomonas inoculated on seeds increased the Leaf Area Index (LAI) arround 44\%, leaf chlorophyll index about $61 \%$, and biomass dry weight by $24 \%$ (Kouchebagh et al. 2012). Azotobacter shows positive effects in increasing maize growth and yield (Wani et al. 2016), plant height, stem thickness, shoot dry weight, root length, root width,

Table 4. Yield of corn in response to the NPK level combined with biofertilizer.

\begin{tabular}{clrrr}
\hline \multirow{2}{*}{ Code } & \multicolumn{1}{c}{ Treatments } & \multicolumn{1}{c}{ WCC } & CGW & GW100 \\
\cline { 3 - 5 } & & $\ldots \ldots \ldots . \mathrm{g} \mathrm{pot}^{-1} \ldots \ldots \ldots$. & $\ldots . \mathrm{g} \ldots .$. \\
\hline P1 & Control & $3.60 \mathrm{a}$ & $3.15 \mathrm{a}$ & $(-$ ) $\mathrm{a}$ \\
P2 & NPK (100\% recommended level) & $197.75 \mathrm{c}$ & $165.68 \mathrm{bc}$ & $32.38 \mathrm{~b}$ \\
P3 & Biofertilizer & $6.90 \mathrm{a}$ & $4.78 \mathrm{a}$ & $(-$ ) $\mathrm{a}$ \\
P4 & NPK (25\% recommended level)+Biofertilizer & $177.66 \mathrm{~b}$ & $145.96 \mathrm{~b}$ & $32.88 \mathrm{~b}$ \\
P5 & NPK (50\% recommended level)+Biofertilizer & $223.84 \mathrm{~d}$ & $190.87 \mathrm{~d}$ & $32.90 \mathrm{~b}$ \\
P6 & NPK (75\% recommended level)+Biofertilizer & $168.14 \mathrm{~b}$ & $142.24 \mathrm{~b}$ & $31.71 \mathrm{~b}$ \\
P7 & NPK (100\% recommended level)+Biofertilizer & $197.75 \mathrm{c}$ & $168.43 \mathrm{c}$ & $35.48 \mathrm{~b}$ \\
\hline \multicolumn{2}{c}{ CV (\%) } & 15.60 & 15.37 & 20.30 \\
\hline
\end{tabular}

Note: The numbers followed by the same letters in the same column show no significant difference at $5 \%$ DMRT. WCC (weight of corn with cobs), CGW (weight of grains), GW100 (weight of 100 grains), (-) the number of grains did not reach to 100 


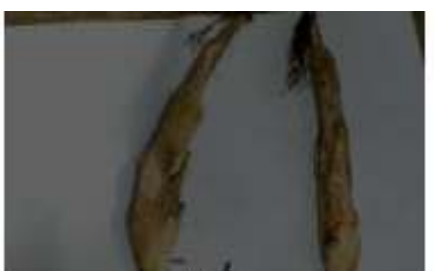

$\mathrm{P} 1$

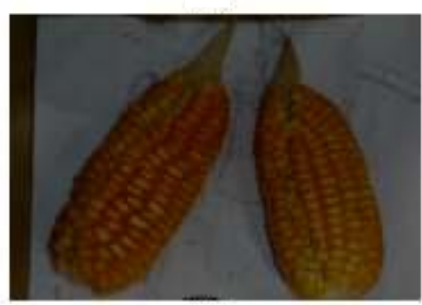

P2

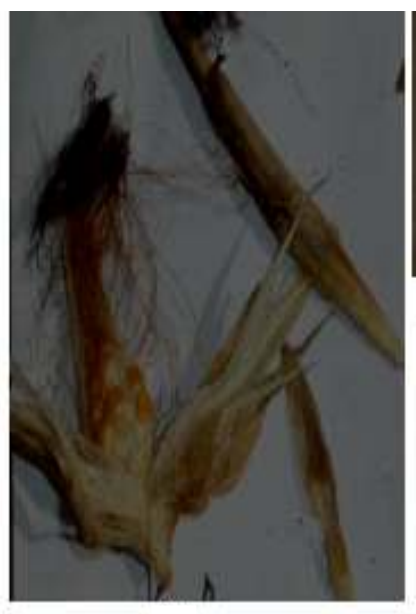

P3

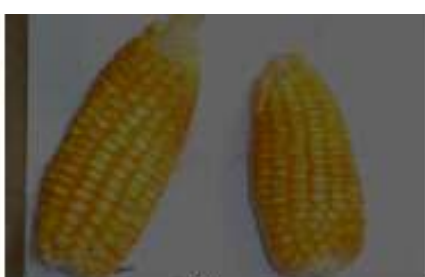

P5

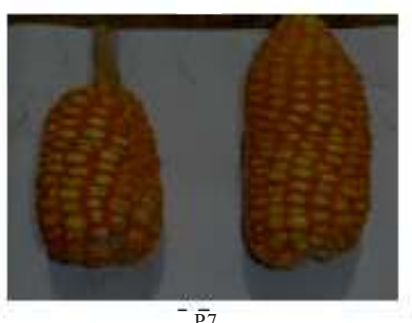

Figure 3. Performance of corn cobs in various treatments.

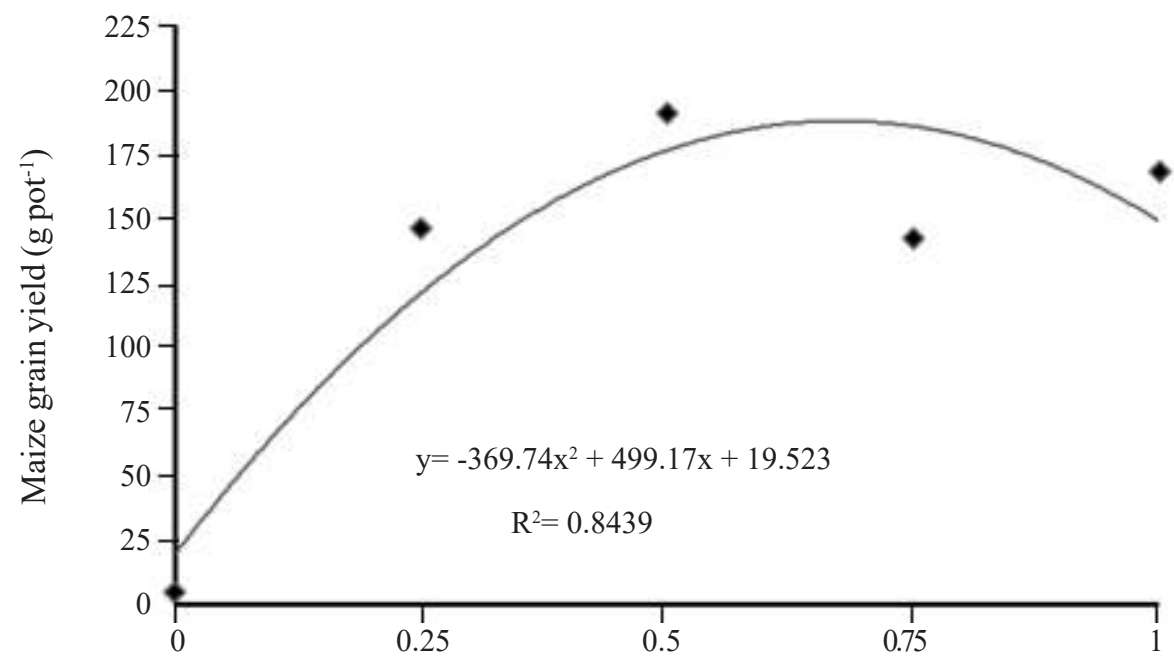

NPK fertilizer dosages

Figure 4. Relationship between the rate of NPK fertilizers combined with biofertilizer on maize grain yield.

and root weight (Mahato and Neupane 2017). Performance of corn cobs in various treatments is presented in Figure 3.

The relationship between NPK fertilizer level (350 kg Urea ha ${ }^{-1}, 100 \mathrm{~kg} \mathrm{SP} 36 \mathrm{ha}^{-1}$ and $75 \mathrm{~kg} \mathrm{KCl}$ $\mathrm{ha}^{-1}$ ) and the weight of maize grains is presented in Figure 4. NPK fertilization combined with biofertilizer can increase the dry weight of grains. Figure 3 shows that the increase of fertilization above 0.75 of NPK recommended doses in combination

Table 5. Relative Agronomic Effectiveness (RAE) in response to NPK fertilizers combined with biofertilizer on maize grains.

\begin{tabular}{cll}
\hline Code & \multicolumn{1}{c}{ Treatments } & RAE (\%) \\
\hline P1 & Control & 0 \\
P2 & NPK (100\% recommended level) & 100 \\
P3 & Biofertilizer & 1.70 \\
P4 & NPK (25\% recommended level)+Biofertilizer & 89.65 \\
P5 & NPK (50\% recommended level)+Biofertilizer & 113.44 \\
P6 & NPK (75\% recommended level)+Biofertilizer & 84.75 \\
P7 & NPK (100\% recommended level)+Biofertilizer & 100 \\
\hline
\end{tabular}


with biofertilizer tends to decrease the weight of maize grains, which is indicated by the regression equation of $Y=-369.74 x^{2}+499.17 x+19.523$. Based on the equation, the plant response on the application of NPK fertilizers plus biofertilizer is indicated by the $\mathrm{R}^{2}$ value of 0.84 . The optimum dose of NPK fertilizers combined with biofertilizer can be calculated as a differential function or the first derivative of the equation $\mathrm{Y}=-369.74 \mathrm{x}^{2}+499.17 \mathrm{x}$ +19.523 .

\section{Effect of NPK and Biofertilizer on Relative Agronomic Effectiveness (RAE)}

The value of relative agronomic effectiveness (RAE) in P3 (biofertilizer treatment) is about 1.70\% (Table 5), indicating that the biofertilizer cannot be used alone and it should be combined with the use of chemical fertilizers. The application of $50 \%$ recommended NPK level+biofertilizer results in the highest RAE value compared to the other treatments, which is about $113 \%$. This value shows that the use of NPK fertilizers accompanied by biofertilizer increases maize yield effectively, indicating a synergetic effect of chemical fertilizers and biofertilizer.

\section{CONCLUSIONS}

Theapplication of $50 \%$ recommended NPK level+biofertilizer results in the highest dry weight of biomass, corn+cobs, and grains. Dry weights of biomass, corn + cobs and grains are 138.09, 223.84 and $190.87 \mathrm{~g} \mathrm{pot}^{-1}$, respectively. Application of biofertilizer on maize cultivation on Inceptisol decreases the use of inorganic fertilizer doses up to half of the recommended level. The optimum doses of NPK fertilizers are Urea, SP36 and $\mathrm{KCl}$ about 200,60 , and $45 \mathrm{~kg} \mathrm{ha}^{-1}$. The application of $50 \%$ recommended NPK level+biofertilizer results in the RAE value of $113 \%$.

\section{ACKNOWLEDGEMENTS}

Our gratefulness goes to PT Indoraya Mitra Persada 168 for their helps during the research in cooperation with Indonesian Soil Research Institute (ISRI).

\section{REFERENCES}

Bais HP, TL Weir, LG Perry, S Gilroy and JM Vivanco. 2006. The role of root exudates in rhizosphere interactions with plants and other organisms. Annu Rev Plant Biol 57: 233-266.
Beyranvand H, A Farnia, SH Nakhjavan and M Shaban. 2013. The response of yield and yield components of maize (Zea mays L.) to different biofertilizers. Int $J$ Adv Biol Biomed Res 1: 1068-1077.

Bhardwaj D, MW Ansari, RK Sahoo and N Tuteja. 2014. Biofertilizers function as key player in sustainable agriculture by improving soil fertility, plant tolerance and crop productivity. Microbial Cell Factories 13: 1-10.

Bhattacharya O and KK Jain. 2000. Phosphorus solubilizing biofertilizers in the whirlpool of rock phosphate challenges and opportunities. Fertilizer News 459: 45-49.

Farnia A and V Ashjardi. 2015. Effect of nitrogen biofertilizers on yield and yield components of different maize (Zea mays L.) cultivars. Int J Life Sci 9: $117-121$.

Isgitani M, S Kabirun and SA Siradz. 2005. Pengaruh inokulasi bakteri pelarut fosfat terhadap pertumbuhan shorghum pada berbagai kandungan P tanah. J Ilmu Tanah dan Lingkungan 5: 48-54.

Kasno A, D Setyorini and E Tuberkih. 2006. Pengaruh pemupukan fosfat terhadap produktivitas tanah inceptisol dan ultisol. J Ilmu-IlmuPertanian Indonesia 8: 91-98. (in Indonesian).

Kouchebagh SB, B Mirshekari and F Farahvash. 2012. Improvement of corn yield by seed biofertilization and urea application. World Appl Sci J 16: 12391242.

Machay AD, JK Syers and PEH Gregg. 1984. Ability of chemical extraction procedures to assess the agronomic effectiveness of phosphate rock material. New Zeal J Agr Res 27: 219-230.

Mahato S and S Neupane. 2017. Comparative Study of impact of Azotobacter and Trichoderma with other fertilizers on maize growth. JMaize Res Dev 3: 1-16

Malusá E and N Vassilev. 2014. A contribution to set a legal framework for biofertilisers. Appl Microbiol Biotech 98: 6599-6607. https://doi.org/10.1007/ s00253-014-5828-Y

Matsumoto H, Y Yamamoto and B Ezaki. 2003. Recent Advances in The Physiological and Molecular Mechanism of Al toxicity and tolerance in higher plants. Adv Plant Physiol 5:29-74.

McCarty SC, DS Chauhan, AD McCarty, KM Tripathi, T Selvan and SK Dubey. 2017. Effect of Azotobacter and Phosphobacteria on yield of wheat (Triticum aestivum). Vegetos-An Int J Plant Res 30: 1-4.

Naserirad H, A Soleymanifard and R Naseri. 2011. Effect of integrated application of bio-fertilizer on grain yield, yield components and associated traits of maize cultivars. Am-Eurasian J Agric Environ Sci 10:271-277.

Ogola JBO, TR Wheeler and PM Harris.2002. Effects of nitrogen and irrigation on water use of maize crops. Field Crop Res 8: 105-117.

Purwaningsih S. 2003. Isolasi, populasi dan karakterisasi bakteri pelarut fosfat pada tanah dari Taman Nasional Bogani Nani Wartabone, Sulawesi Utara. Biologi 3: 22- 31. (in Indonesian). 
Rahman MA, SH Lee, HC Ji, AH Kabir, CS Jones and KW Lee. 2018. Importance of mineral nutrition for mitigating aluminum toxicity in plants on acidic soils: current status and opportunities. Int J Mol Sci 19: 3073-3090. https: //doi.org/10.3390/ijms19103073

Rahmansyah M, S Antonius and N Sulistinah. 2009. Phosphatase and urease instability caused by pesticides present in soil improved by grounded rice straw. ARPN J Agric Biol Sci 4: 56-62.

Rokhzadi A, A Asgharzadeh, F Darvish, NM Ghorban and M Eslam. 2008. Influence of plant growthpromoting rhizobacteria on dry matter accumulation and yield of chickpea (Cicer arietinum L.) under field conditions. Am Eurasian J Agric Environ Sci 3:253-257.

Santosa E. 2009. Aktivitas beberapa isolat bakteri pelarut fosfat pada berbagai kadar C organik di tanah ultisol. Dalam: Prosiding Seminar dan Lokakarya Nasional Inovasi Sumberdaya Lahan. Teknologi Konservasi, Pemupukan, dan Biologi Tanah. Buku II: 1-14. Bogor: Balai Besar Penelitian dan Pengembangan Sumberdaya Lahan Pertanian. (in Indonesian).

Simanungkalit RDM. 2001. Aplikasi Pupuk Hayati dan Pupuk Kimia: Suatu Pendekatan Terpadu. Buletin Agro Bio 4: 56-61. (in Indonesian).

Simanungkalit RDM, DA Suriadikarta, R Saraswati, D Setyorini and W Hartatik. 2006. Pupuk Hayati. Badan Penelitian dan Pengembangan Pertanian. Bogor. (in Indonesian).

Sivamurugan AP, R Ravikesavan, AK Singh and SL Jat. 2018. Effect of different levels of $P$ and liquid biofertilizers on growth, yield attributes and yield of maize. Chem Sci Rev Lett 7: 520-523.
Stamford NP, SS Junior, CERS Santos, ADS Freitas, CMA Santos, TMS Arnaud and HR Soare. 2014. Yield of grape (Vitis labrusca cv. Isabel) and soil nutrients availability affected by biofertilizers with diazotrophic bacteria and fungi chitosan. Aust $J$ Crop Sci 8: 301-306.

Wani SA, S Chand, MA Wani, M Ramzan and KR Hakeem. 2016-. Azotobacterchroococcum-A Potential Biofertilizer in Agriculture: An Overview. In: K Hakeem, J Akhtar and M Sabir (eds). Soil Science: Agricultural and Environmental Prospectives. Springer, Cham, pp: 333-348. https://doi.org/10.1007/ 978-3-319-34451-5_15

Wong WS, SN Tan, L Ge, X Chen and JWH Yong. 2015. The importance of phytohormones and microbes in biofertilizers. In: DK Maheshwari (Ed). Bacterial Metabolites in Sustainable Agroecosystem. Springer, pp. 105-158. https://doi.org/10.1007/9783-319-24654-3.

Wu SC, ZH Cao, ZG Li, KC Cheung and MH Wong. 2005. Effects of biofertilizer containing $\mathrm{N}$-fixer, $\mathrm{P}$ and $\mathrm{K}$ solubilizers and AM fungi on maize growth: a greenhouse trial. Geoderma 125: 155-166.

Yousefi A A, Khavazi K, A Moezi A, F Rejali and HA Nadian. 2011. Phosphate solubilizing bacteria and arbuscular mycorrhizal fungi impacts on inorganic phosphorus fractions and wheat. World Appl Sci J 15: 1310-1318.

Zahir AZ, MArshad and A Khalid. 2004. Improving Maize Yield by Inoculation with Plant Growth Promoting Rhizobacteria. Pak J Soil Sci 15: 7-11. 